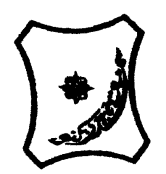

Bayero Journal of Pure and Applied Sciences, 8(2): 192 - 195

Received: August, 2015

Accepted: November, 2015

ISSN $2006-6996$

\title{
CHEMICAL EQUIVALENCE ASSESSMENT OF THREE BRANDS OF CARBAMAZEPINE TABLETS AND THEIR ANTICONVULSANT OUTCOME ON ELECTRICALLY-INDUCED SEIZURES IN CHICKS
}

\author{
Malami $^{1}$, S., Usman ${ }^{2}$, A.M., Shehu ${ }^{3}$, M.A., and Yerima ${ }^{4}$, M. \\ 1- Department of Pharmacology, Bayero University, Kano, Nigeria \\ 2- Department of Pharmaceutical and Medicinal Chemistry, Ahmadu Bello University, Zaria, Nigeria \\ 3- Department of Clinical Pharmacy and Pharmacy Practice, Ahmadu Bello University, Zaria, Nigeria \\ 4- Department of Pharmacology, Usmanu Danfodio University, Sokoto, Nigeria \\ Corresponding Author: malamisani@gmail.com; +2348039701420
}

\begin{abstract}
Assay for content of active ingredients is a critical test of drug quality; failure to meet up the standard for content of active ingredients will result to sub therapeutic quantities. Three brands $(A, B$ and $C)$ of carbamazepine were assayed to determine their chemical equivalence as well as their anticonvulsant activities. This was aimed at determining the possible relation between the chemical equivalence of the brands and their anticonvulsant outcomes. The brands were randomly selected from Community Pharmacies in Zaria, Kaduna State, and assayed for chemical equivalence to establish weight uniformity and identity; percentage content of active ingredients, using UV spectrophotometric analysis. Similarly all the brands were evaluated for anticonvulsant activity using maximal electroshock seizure model in chicks at doses of 20,10 and $5 \mathrm{mg} / \mathrm{kg}$. All the brands passed weight uniformity test as none of the tablets deviated from the mean by more than $7.5 \%$. Similarly, their melting points were found to conform to standard average melting point $\left(191^{\circ} \mathrm{C}\right)$ according to B.P. official monograph. However, the content of the active ingredients for Brands $B$ and $C$ did not conform to official standard of $95-105 \%$ while brand $A$ conformed. Thus, the percentage contents for brands $A$, $B$ and $C$ were $99.49 \%, 76.02 \%$ and $87.59 \%$ respectively. Also, all the brands at the tested doses offered protection against seizures, ranging from 70-100\%; but Brand C at $5 \mathrm{mg} / \mathrm{kg}$ offered only $40 \%$ quantal protection. The three brands of carbamazepine tablets were not chemically equivalent and their chemical equivalence indices could not be said to be the determinant of anticonvulsant effect. Key words: carbamazepine, anticonvulsant and chemical equivalence
\end{abstract}

\section{INTRODUCTION}

Two pharmaceutical products are said to be chemically equivalent if they have identical active ingredients and are identical in strength or concentration and dosage form (Usman, 2010). Where as, they are bioequivalent when they are pharmaceutically equivalent and their bioavailabilities after administration in the same molar dose are similar to such a degree that their effects, with respect to both efficacy and safety, can be expected to be essentially the same (Najib et al., 2004). Epilepsy is the most common non-infectious neurologic disease in developing African countries, including Nigeria and remains a major medical and social problem (Ogunrin, 2006). Thus, it imposes a large economic burden on global health care systems and is a major public health problem in low and middle-income countries (Mbuba and Newton, 2009). Carbamazepine is used in the treatment of trigeminal and glossopharyngeal nerve neuralgia, acting by reducing repetitive activation of the action potential (Solon et al., 2010). It is considered one of the best anticonvulsant, producing less psychological alterations and behavior effects
(Castro et al., 2010). Previous study was conducted by Solon et al., (2010) to evaluate the physico-chemical quality control of some formulations of carbamazepine. This study was aimed to assay the chemical contents and some physical parameters of three brands of carbamazepine; by determining possible relationship between the chemical equivalence of the brands and the outcomes of seizure protection in chicks, using maximal electroshock test.

MATERIALS AND METHODS

Electrothermal melting point apparatus (Model 2038A England); Ugobasile Electroconvulsive Machine (Model 7801); UV Spectrophotometer (Helios Zeta, Thermoscientific U.K.); Oven, Water Bath; Analytical Balance, Thermometer and Glass Wares. Ethanol and Acetone -BDH chemical (England); Three brands of carbamazepine tablets were randomnly purchased from different Pharmacies in Zaria, Nigeria. The three brands were registered with National Agency for Food, Drugs Administration and Control (NAFDAC) as evidence of fulfilling the requirement of the agency, Tegretol $^{R}$ was considered the innovator brand while the other two as generics. 
Day-old Chicks (24-36 g) were obtained from Ota Farm, Ogun State, Nigeria, and brought to Animal House, Department of Pharmacology and Therapeutics, Ahmadu Bello University, Zaria. They were allowed to acclimatize before commencement of the experiment.

\section{METHODS}

\section{Uniformity of Weight:}

Twenty (20) tablets of each brand of carbamazepine were weighed on an analytical balance, the individual weights were recorded and the mean weight as well as standard deviation for each brand was calculated. The official specification (BP 2002) with respect to variation in weight of tablets states that for a tablet weighing $200 \mathrm{mg}$, not more than two of the tablets should deviate from the mean weight by greater than $7.5 \%$ and none should deviate by twice the percentage $(15 \%)$.

\section{Identification of Carbamazepine}

A quantity of powdered tablets containing $0.2 \mathrm{~g}$ of carbamazepine was boiled with $15 \mathrm{ml}$ of acetone, the hot solution was filtered and the filtrate washed with two $5 \mathrm{ml}$ quantities of hot acetone, the combined filtrate was evaporated to $5 \mathrm{ml}$ and cooled on ice. The crystals formed were washed with acetone and dried at $70^{\circ} \mathrm{C}$ for 30 minutes. The melting point of the crystals was determined. The official melting point of the crystals should be $191{ }^{\circ} \mathrm{C}$ as specified in (BP 2002). The entire procedure was repeated for each of the other two brands.

\section{Assay of Carbamazepine}

A quantity of the powdered tablets containing $60 \mathrm{mg}$ of carbamazepine was boiled with $25 \mathrm{ml}$ of ethanol (96\%) for a few minutes; the hot mixture was stirred in a closed flask for 10 minutes and filtered; sufficient ethanol was added to the cooled filtrate to produce $100 \mathrm{ml}$. About $5 \mathrm{ml}$ was pipetted into $250 \mathrm{ml}$ volumetric flask and the volume made up to $250 \mathrm{ml}$ with ethanol. The absorbance of the resulting solution was measured using UV spectrophotometer at the maximum at $285 \mathrm{~nm}$. The content of the drug was calculated taking $490 \mathrm{~nm}$ as the value of $\mathrm{A}(1 \%, 1 \mathrm{~cm})$ at the maximum at $285 \mathrm{~nm}$. The entire procedure was repeated for the other brands. Drugs were expected to contain 95 to $105 \%$ of the active pharmaceutical ingredient to be of acceptable quality (BP, 2002).

Maximal Electroshock-induced Seizures in Chicks

This experiment was conducted according to Swinyard and Kupferberg (1985) and Swinyard et al., (1989). Ten groups each containing 10 chicks were used; group 1 served as control and received normal saline $(10 \mathrm{ml} / \mathrm{kg}) ;$ groups 2,3 and 4 received graded doses (5, 10 and $20 \mathrm{mg} / \mathrm{kg}$, respectively) of Brand A; groups 5, 6 and 7 received Brand $B$; and groups 8,9 and 10 received Brand $C$, each at same graded doses as Brand A. Thirty minutes post-treatment, seizures were induced to all the groups using Ugobasile electroconvulsive machine (Model No. 7801) with corneal electrodes placed on the upper eyelids of the chicks. The current, shock duration, frequency and pulse width were set and maintained at $85 \mathrm{~mA}, 0.8 \mathrm{~s}$, $100 \mathrm{~Hz}$ and $0.6 \mathrm{~ms}$, respectively. The ability of each brand at varying doses to prevent Tonic Hind Limb Extension (THLE) in chicks was considered as an indication of anticonvulsant activity (Sayyah et al., 2002).

\section{ANALYSIS OF RESULTS}

The results were expressed as Mean \pm Standard Error of Mean and Percentages where appropriate.

\section{RESULTS}

The three brands of carbamazepine tablets have reasonable shelf life as shown (Table 1 ). None of the brand failed weight uniformity test as they did not deviate from the mean by more than $7.5 \%$ as specified in the official compedium (BP 2002) (Table 2). Identification test showed that all the brands contained carbamazepine as their active ingredients. Thus, each brand has its melting temperature within the official range of $191^{\circ} \mathrm{C}$ (Table 3). Brand $\mathrm{A}$ contained the required content of the active ingredient while Brands $B$ and $C$ did not contain required amount (Table 4). All the brands exhibited good anticonvulsant activity; with at least $80 \%$ seizure protection except for Brand B $(40 \%$ protection $)$ at 5 mg/kg.

Table 1: Manufacturers Description of the Three Carbamazepine Brands

\begin{tabular}{|c|c|c|c|c|c|}
\hline Brand & Batch No & $\begin{array}{l}\text { Manufacturing } \\
\text { Date }\end{array}$ & Expiry Date & No & Country Made \\
\hline$A$ & 70287 & February 2008 & February 2013 & $04-0024$ & Switzerland \\
\hline B & AK07621 & July $\quad 2009$ & July $\quad 2012$ & $04-0685$ & Malaysia \\
\hline C & 090202 & February 2009 & February 2012 & A4-2318 & China \\
\hline
\end{tabular}

Table 2: Weight Uniformity Test for the Three Brands of Carbamazepine

\begin{tabular}{lccc}
\hline Brand & $\begin{array}{c}\text { Mean Weight } \\
(\mathbf{m g}) \pm \text { SD }\end{array}$ & $\begin{array}{c}\mathbf{> 7 . 5 \%} \text { deviation } \\
\text { from mean weight }\end{array}$ & Remarks \\
\hline A & $273 \pm 6.40$ & None & Passed \\
B & $287 \pm 8.29$ & None & Passed \\
C & $301 \pm 8.53$ & None & Passed \\
\hline
\end{tabular}


Table 3: Identification Test for the Three Brands of Carbamazepine

\begin{tabular}{lccc}
\hline Brand & $\begin{array}{l}\text { Melting Point } \\
\text { Range }\left({ }^{\circ} \mathbf{C}\right)\end{array}$ & $\begin{array}{l}\text { Average Melting } \\
\text { Point }\left({ }^{\circ} \mathbf{C}\right)\end{array}$ & Remarks \\
\hline A & $189-194$ & 191.5 & Passed \\
B & $190-194$ & 192.0 & Passed \\
C & $190-195$ & 192.5 & Passed \\
\hline
\end{tabular}

\begin{tabular}{lcc}
$\begin{array}{l}\text { Table 4: Assay for the Three Brands of Carbamazepine } \\
\text { Brand }\end{array}$ & $\begin{array}{c}\text { Percentage } \\
\text { Remarks }\end{array}$ & Content (\%) \\
\hline A & 99.49 & Passed \\
B & 76.02 & Failed \\
C & 87.59 & Failed \\
\hline
\end{tabular}

Table 5: Protective Effects of Carbamazepine Brands on Maximal Electroshock-induced Seizures in Chicks

\begin{tabular}{lcc}
\hline Groups & Dose $\mathbf{( m g / k g )}$ & $\begin{array}{c}\text { Protection against } \\
\text { Seizures (\%) }\end{array}$ \\
\hline Normal saline & $10 \mathrm{ml} / \mathrm{kg}$ & 0.0 \\
Brand A & 5 & 80.0 \\
& 10 & 90.0 \\
Brand B & 20 & 100.0 \\
& 5 & 80.0 \\
& 10 & 90.0 \\
Brand C & 20 & 90.0 \\
& 5 & 40.0 \\
& 10 & 80.0 \\
& 20 & 100.0 \\
\hline
\end{tabular}

\section{DISCUSSION}

Uniformity serves as a measure for good manufacturing practice (GMP) as well as amount of the pharmaceutical ingredient (API) in a product (Ngwuluka et al.. 2009). The conformity of the assayed brands to this test indicated good quality assurance in the manufacturing process of the tablets. From the results obtained, all the studied brands showed the presence of carbamazepine (Table 3). This was supported by their melting temperature ranges, as melting point was used as a physical index for the tablet identification. The contents of Brand $A$, an innovator brand, conformed to the standard (BP 2002) while that of Brands $B$ and $C$ did not conform (Table 4). Bioavailability is the fraction of the administered drug which reaches the blood stream from the gastrointestinal tract (Solon et al., 2010). Thus, the amount of the active ingredient presence in a drug is one of the determinants of bioavailabilty. Therefore, Brand A might be more bioavailable compared to other brands.

Maximal electroshock model induces convulsion by facilitating $\mathrm{Ca}^{2+}$ and $\mathrm{Na}^{+}$entry into the cells (Inan and Buyukafsar, 2008); thus, their blockade can prevent the MES-induced tonic extension (Bum et al., 2010). Protection against hind limb tonic extension (HLTE) in the MEST predicts anticonvulsant activity of antiepileptic drugs (e.g phenytoin, carbamazepine, oxcarbazepine, and lamotrigine) that prevent the spread of seizure discharge from an epileptic focus during seizure activity (Browning, 1992). Thus, indicates the ability of the antiepileptic agent to serve in the treatment of generalized tonic-clonic and partial seizures (Raza et al., 2001). Carbamazepine limits repetitive firing of nerve action potentials and it shows neuronal sodium channel blocking characteristics of high affinity for the inactivated state of the channel (Lipkind and Fozzard, 2010). All the brands, except Brand $B$ at lowest dose, gave similar protection against seizure occurrence and thus, exhibited good efficacy (Table 5).

\section{CONCLUSION}

The studied brands were not chemically equivalent but that did not affect their anticonvulsant outcomes. Therefore, the content of the drug did not seem to directly translate to the biological activity as demonstrated in this work.

ACKNOWLEDGEMENT: We thank M. Iliya, Department of Pharmaceutical and Medicinal Chemistry, Ahmadu Bello University, Zaria, for his technical assistance. 


\section{REFERENCE:}

British Pharmacopoeia (2002). Volume I and II Her Majesty's Stationary Office, University Press Cambridge, London, UK, pp. 1105-1112.

Browning, R. (1992). The electroshock model, neuronal network and antiepileptic drugs. In: Drugs for Control of Epilepsy: Actions on Neuronal Networks in Seizure Disorders, Faingold, C.L., Fromm, G.H. (Eds). CRC press: Boca Raton, FL, pp. 195-211.

Bum, E.N., Nkantchoua, G.N., Njikam, N., Taiwe, G.S., Ngoupaye, G.T. and Pelanken, M.M. (2010). Anticonvulsant and sedative activity of leaves Senna spectabilis in mice. International Journal of Pharmacology, 6: 123-128.

Castro, A.P.B. M., Redmershi, M.G., Pastorino, A.C., Paz, J.A., Formin, A.B.F., Jacob, C.M.A. (2010). Secondary hypogammaglobinemia after use of carbamazepine: case report and review. Review Hospital Clinic Faculty of Medicine, 56(6): 189-192.

Inan, S.Y. and Buyukafsar, K. (2008). Antiepileptic effects of two Rho-kinase inhibitors, Y-27632 and fusudil, in mice. British Journal of Pharmacology, 155: 44-51.

Lipkind, G.M. and Fozzard, H.A. (2010). Molecular Model of Anticonvulsant Drug Binding to the Voltage-Gated Sodium Channel Inner Pore. Molecular Pharmacology, 78(4): 631-638.

Mbuba, C.K. and Newton, C.R. (2009). Packages of care for epilepsy in low and middle-income countries. PLos Medicine, 6(10): 1-7.

Najib, N., Nasir, I. and Besthtawi, M. (2004). Bioequivalence evaluation of brands of aceclofenac. Biopharmaceutical and Drug Disposition, 24(2): 103-108.

Ngwuluka, N.C. , Lawal, K., Olorunfemi, P.O. and Ochekpe, N.A. (2009). Post-market in vitro bioequivalence study of six brands of ciprofloxacin tablets/caplets in Jos, Nigeria. The Scientitific Research and Essay, 4(4): 298-305.

Ogunrin, A.O. (2006). Epilepsy in Nigeria - A review of etiology, epidemiology and management. Benin Journal of Postgraduate Medicine, 8(1): 27-51.

Raza, M., Shaheen, F., Choudhary, M.I., Suria, A., Attaur-Rahman, Sombati, S. and DeLorenzo, R.J. (2001). Anticonvulsant activities of the FS-1 subfraction isolated from roots of Delphinium denudatum. Phytotherapy Research, 15: 426-430.

Sayyah M, Valizadeh J, Kamalinejad M. (2002). Anticonvulsant activity of the leaf essential oil of Laurus nobilis against pentylenetetrazole and maximal electroshock-induced seizures. Phytomedicine, 9:212-216.

Solon, L.G.S., Oliveira, A.I.M., Guerra, G.C.B. Soarses, L.A.L. and Araujo, A.A. (2010). Determination of carbamazepine in pharmaceutical formulations. Brazilian Journal of Pharmaceutical Sciences, 46(3): 509-513.

Swinyard, E.A. and Kupberg, H.J. (1985). Antiepileptic drugs: detection, quantification and evaluation. Fed proc. 44: 39-43.

Swinyard, E.A., Woodhead, J.H., White, H.S. and Franklin, M.R. (1989). General principles: experimental selection, quantification and evaluation of anticonvulsants. In: Antiepileptic Drugs, Third Edition, Levy, H., Mattson, R.H., Melrum, B., Penry, J.K. and Dreifuss, F.E. (eds.), New York, Raven Press, pp. 85-102.

Usman, M.A., Eniolorunda, R.O., Sule, M.I., Hassan, H.S., Salisu, I.M., Sallau, A. and Bashir, D.B. (2010). Chemical equivalence studies of four brands of metronidazole tablets. Nigerian Journal of Pharmaceutical Sciences, 9(1): 3238. 